\title{
A new beginning, a great challenge: metamodern psychology (Part II)
}

\section{Mihai Șleahtițchi}

Mihai Șleahtițchi - Doctor habilitat (docteur d'État) in Psychology, PhD in Paedagogy, Professor, Republic of Moldova

As the space of the present analysis does not permit discussion of other examples illustrating the perspectivels of modern psychology(22), we shall propose in the following a synthetic view on its metamodern profile, being convinced that our approach based on the information available in this moment - could represent a complex ideatic construction, capable of covering at least nine directions for its elucidation.

Firstly, we are convinced that the psychology of metamodernity will not leave aside "the great problems of the past", paying sufficient attention to the "hot topics" debated upon both in the modern and postmodern epoch. Paraphrazing, to some extent, P. Fraisse, we could say that metamodern psychology will follow, in various ways, the modern and postmodern one, so that "to be able to anticipate the domains and results to follow". Obviously, it goes without saying that, during metamodernity, the large variety of concepts, orientations and domains developed in modernity and/ or postmodernity will create difficulties related to the unification of psychology. Accordingly, as already mentioned, and citing M. Richelle, the psychology of metamodernity will continue to be characterized by a sort of epistemological syncretism. In such a sitiation, the gathering effort should imply at least four essential traits: a new reading of the theoretical approaches ("not only for evidencing their common denomiator, which would involve their devoiding of any substance, but also for revealing the issues to be faced, which they cannot solve, any more; it is only in this domain that all chances for attaining convergency and complementarity may be found"); terminological explanations ("in not few cases, the same idea is expressed in different words, or different thing are reffered to in the same words; to rediscover and identify things, one should leave aside the words"); a radical modification of the main approach ("instead of laying stress on explanatory - partial or totalitarian - models, more recommended is to re-establish the priority of issues, after which the theoretical models may be obtained"), and a reexamination of the methods ("study of some 
aspect by several methods as, in too many cases, the method employed is selected precisely for checking the theory"). In all likelihood, distancing between the external and the internal observation, as well as the convergence between connex domains (for example, development of biotechnology has stimulated and will continue to stimulate biopsychological researches) will increase. Equally, cognitive psychology, the psychology of information processing, physiological and genetic psychology will advance.

Secondly, we are inclined to assert that the scientific psychology of the metamodern epoch will establish its own outlook regarding the human being. Under the new historical conditions, we repeat that "the postmodern culture of relativism" is doomed to fail, which means that it will be gradually substituted by a post-ideological condition centered on involvement and affectation. In such a context, most probably, the human being will be viewed as an oscillating structure susceptible of including "certainty and doubt, hope and melancholy, sincerity and irony, feeling and apathy, personal and impersonal attitudes, technicism and technology". On any occasion and under any circumstances, it will have to demonstrate that the philosophy of life it imparts, and also what it busily promotes, is based on a "pragmatic neoromanticism" (susceptible to create a symbiosis between two types of culture - that of utility and that of dignity), on a "new type of sincerity" (capable of denying both the ideological credulity imposed by the modern epoch, and also the cynical skepticism of the postmodern times), a "new rationalism" (centered on a consistent identification and promotion of the scientific truth), a "new type of hedonism" (ready to give priority to the present time, rendering to the most recent events adaptative positive significance), a receptivity towards narrow social environment, on "the small cultural traditions" and territorial identities, on a "network logic" (prepared to approach the everyday life according to a complex thinking pattern), a lattice of interpreting reality adapted to "post-truth" (capable to fully develop critical thinking), a fully transparent code of manners (conferring visibility and distinctness to behavioral acts) and/ or a series of states whose name begins with "trans-", an element of pedantic composition, meaning "over" or "beyond (of)" (such as that of transgender or of transgression, transhumanism or transmission). More than that, while strictly following "the spirit of the age", it will have to demonstrate that it is capable of decyphering the events and phenomena of the world to which it belongs based on data extracted from reality, that it may reconstruct itself by the organization and realization of inter-relational type communications, that it has the capacity to see things in all their depth and that it promotes an existential order in which all - small and big, common and less common - things express a unitary logic(23). As a result of the reinterpretations on the human being and his/ her role under the new historical conditions, we shall most probably witness an ample development of the psychological sciences (considering here mainly social psychology, cognitive psychology, introspective psychology, the psychology of communication, behavioural psychology and/ or patological psychology) focused on the "psychic substance" of the human being - especially on his/ her affectivity and capacity of involvement along with a decline of the psychological sciences which, in the past, neglected human's inner world (for example, behavioristic psychology).

Thirdly, it is quite possible that, in the years to come, the science of psychology will be 
mainly and thoroughly devoted to the study of self-organization and creative activism. As already observed, metamodernity is interested in the intellectual strategies with "oscillating" nature, substituting the "or/ or" principle with the "and/ and" one, so that the necessity of identifying the manner in which two or more contradictory conditions can be simultaneously experienced might possibly appear. Or, in the case in which such "swingings" (namely, movements of the "come-and-go" type) play a determining part, establishment of a close connection between the significance of decentralization at external level and self-organization at internal level, a connection which will correlate personal autonomy with civic responsibility and its moral maturity, is highly expected. In such a context, it is not only selection of a certain "pole", but grasping of the pulsating character of objective reality that will constitute the essence of the knowledge and of social adaptation processes. Obviously, for facing the intellectual stress of such situations, each person will simply have to resort to various syntheses of creative nature, that will force him/ her to invent new things. Therefore, in one way or another, selforganization and creativity acquire defining characteristics of the metamodern individual and, respectively, metamodern psychology(24).

Fourthly, further evolution of psychology preponderantly oriented to turning to good account epistemological constructions of pragmatic type, self-reconstruction through inter-relational communication, capacity of involvement or affectivity - will finally lead to the elaboration of some new concepts, of purely metamodern nature. In parallels with the notions invented and fully advanced either in the modern epoch(such as, for example, that of social role (proposed by F. La Rochefoucauld in 1655), that of public opinion (proposed by J.-J. Rousseau in 1744), that of aculturation (proposed by W.H. Holmes, F. Bocs and W.J. McGee in the end of the XIXth century), that of ambivalence (proposed by E. Bleuler in 1910), that of eros (proposed by S. Freud in 1920) or that of habit (proposed by J. Dewey in 1922), or in the postmodern one(such as, for example that of social representations (proposed by S. Moscovici in 1961), that of real conflict (proposed by M. Sherif in 1966), that of autopoiesis (proposed by U. Maturana and F. Varela in 1975), that of cript (proposed by $\mathrm{N}$. Abraham and M. Torok in 1978) that of social impact (proposed by B. Latané and S. Wolf in 1981), that of sexism (proposed by J.E. Williams and D.L. Bert in 1982) or that of mcdonaldization (proposed by G. Ritzer in 1993)) - which, undoubtedly, will remain strictly actual, a new series of previously unknown notions will appear, for example, the concept of proteism or that of metaxypsychology.

Discussing the essence of the concept of proteism, its author, M.N. Epshtein, considers that the state of mind prevailingly manifested in the beginning of the XXIst century may be described with expression "proto-", a fundamental linguistic element of pedantic composition, of Greek origin, meaning "the main", "the first", "the early". Using the term "proto-", says M.N. Epshtein, means to recognize that this century lays the foundations of an unknown civilization, in which all our previous knowledge represents only too few discoveries, comparatively with we ought to know in an epoch characterized by a massive presence of info- and biotechnologies. This notion is expected to express: (i) the human capacity of being oriented and, respectively, prepared to face a doubtful future, (ii) awareness upon the embryonary-arhaic form of our present conduct (as, for the moment, each of us 
s.

represents both an embryo of the civilizations

to come, and an immemorial relict of theirs), and (iii) openess towards transitivism (which agrees with the fundamental expression of the mythological Proteus), towards dynamicity and fluidity, towards everything existing and manifesting in either amorphous or polymorphous state (25).

The observation to be made about the second concept is that its author - A.A. Grebeniuk starts from the idea that, in the metamodern epoch, "the exact science of the mind and of the human conduct" should be necessarily developed in the "metaxy" variant, which means that its specificity should be simply reduced to "a continuous movement between and outside some contradictory poles". Inspired by the studies of P. Friedlander, L. Herman and R. Eshelman, he states that such a new vision is actually expressing a critical reaction both against the contradictions present in the naive ideologies of the time and against the pseudo-scientific theories of postmodernism. Finally, metaxypsychology is expected to offer the necessary conditions for the development of non-ideologized and nonironical scientific projects. With such a general objective in view, it will grant that the systematic study of human mentality and conduct will become organically related to art, imagination and creativity. More than that, while oscillating between the modern tradition of "searching of meaning" and the postmodernist trend of "neglecting the meaning", metaxypsychology will be responsible for creating some authentic representations of the human being, in his/ her quality of "behavioural entity endowed with perception, intellect and affectivity". Continuing to ceaseslessly modify the tendencies of modernist and postmodernist origin, it will contribute to demonstrating that, for now, the ideas of the "our life is a game" type should not be taken seriously, any more, being replaced by a wholly different postulate: "our life is a performance". Leaving aside the concepts of "good" and "evil", this assumption will show the way through which reality may be thoroughly reflected, providing an interpretation of events and facts in which interpretative dualism and uncertitude will be either hardly manifested or they will be absent. The form will follow the content, which means that things considered once as intricated, obscure and difficult to understand will become simple, distinct and easy understandable. In such a moment, the neoromantic character of metaxypsychology will find its expression as an oscillation between order and chaos, form and non-form, beautiful and ugly, sublime and horrible. Against such a background, self-therapeutical manifestations will become reality. Equally, it will be manifested as self-assertion and as creation of cronotopes capable of correctly and rapidly orienting one in extremely complicated contexts (26).

Oscillating between the epistemological poles of the modern and postmodern world, at a pace which will involve not only their "exploitation", but equally their "elevation", the new concepts will decisively contribute to a more thorough knowedge about the essential characteristics of the human species and also about its specific manifestations along the third millenium.

Fifthly, we make common cause with the observers who believe that, in an epoch deeply troubled by globalization - a complex phenomenon "whose result is that events occurring in some part of the world have more and more ample repercussions upon societies and issues from other parts of the globe" - the science of psychology will have to elaborate well-structured interpretative methods approaching the flows of persons (migration), of capital and of technology, 
Bulletin of Integrative Psychiatry $\bigcirc$ New Series $\bigcirc$ June $2021 \bigcirc$ Year XXVII ONo. 2 (89)/97

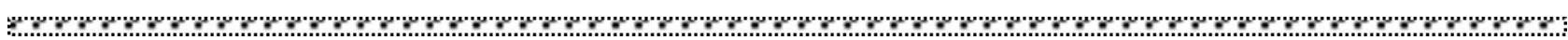

suprapopulation, fragmentation and weakening of social cohesion, modifications produced in technology and innovation, drastic fall of the cultural and national values under the pressure exercised by the progress of the new information and communication techniques, increased inequalities at both internal and external level, destruction of the classical system of values hierarchization, the possibility of an atomic war, spreading of infectious diseases (with special reference to the new types of pandemic virusi), sexism and rasism, ethnocentrism and ultranationalism, proliferation of arming and of transnational crime and/ or of international criminal organizations and therorist nertworks.

It stands to reason that, in the years to come, psychology will have to be correlated "with the great cahllenges of the time and with the possibility of achieving a long lasting international peace beyond the barriers of social policy"(27). Undoubtedly, this will bring about substantial modifications in the communication among psychologists all over the world. Or, as many of the specialists in this field - for example, Virginia Staudt Sexton(28) - anticipate, "the science and profession of psychology will develop if the psychologists of all countries will pay more attention to one another".

Sixthly, we may reasonably assume that, in the new historical conditions, when prevention or combat of the consequences of natural cataclysms(29) and technogenous type catastrophes(30) will play an extremely important part, psychology is expected to provide convincing answers about the behavioural strategies people should adopt in cases of "unexpected, tragic, disastrous events". Most probably, in such a context, studies devoted to the identifiction and practical application of the strategies of psychological protection against (chemical, radioactive, etc.) contaminations, (aviatic, maritim, railway, car, etc.) accidents, hurricanes, typhoons, earthquakes, tsunamis, volcanic eruptions, landslides, draught or floods, will be extremely actual.

Seventhly, we are prone to believe that metamodernity will favourize the infiltration of psychology in domains of activity previously neglected by it, either because they were not of interest or because, in general, they gave no "signs of life" (such as: international consulting, international organizational psychology, multiculturalism, mediation and negociation of interoganizational conflicts, international arbitration, etc.). Such an extension will require revisions both in the programs of psychologists' professional training and in the strategies and techniques of psychologic investigation.

Eighthly, the existing data shows beyond any doubt that, in metamodernity, the evolution of psychology will depend, to a considerable extent, on the progress registered in other domains of scientific research. In this respect, a special part will be played by the ecological and medical sciences, by electronics and technology of information, research of the cosmic space and of the individual, organizational, regional, national, planetary security. The impact will be rapid and intense and no one will have doubts as to the inevitable instauration of a new investigational frame. As part of an intense reaction of epistemological interpenetration, psychology will extend its sphere of interest, creating a new type of paradigms (such as, for example, ambiental psychology, psychoinformatics, psychobionics, psychobiotics, psychoaxiology and / or psychoanthropology). More than that, in the years to come, psychology will be obliged to thoroughly observe the "rules" of 
(2)

transdisciplinarity. Or, the deeply contradictory character of the new daily reality will make it systematically resort to a manner of thinking combining the analyitical perspective with the holistic expression. The socialization and individualization phenomena will create an unifying antinomy expected to explain that, in the new historical conditions, a full social affirmation involves individual resistance to the multiple disagreements manifested in such areas. As a matter of fact, in the metamodern epoch, most likely, psychology will propose investigation paths according to which the analyzes centered on the human being and on the manner in which he/ she advances in life will take into consideration the existing antinomies and the ideas strictly manifested on multiaspectuality, situationality, inter- and trans-disciplinarity(31).

Finally, ninthly, the existing data permits the assertion that, in the metamodern epoch, evolution of psychology will be highly influenced by the principles of market economy. In order "to keep pace with time", it needs a substantial financial support, whose obtaining will require full joining to a system in which "the decisions on the production and distribution of goods are relying on the demand-supply interaction". Along the historical period here analyzed, psychology will have to gain a large social approval, and a considerable social interest. In other words, as M. Zlate puts it(32), it will have "to consider much more people's social problems, to venture beyond the laboratoy and the clinic, to approach the society - the social laboratory". As a matter of fact, this would involve promotion of the principles of psychology in the world of business, creation and large-scale approaching of managerial and entreprising projects capable of assuring maximum efficiency of all activities in the domain. Considerable efforts should be undoubtedly necessary for the identification of new methods for staff recruiting and selection, for the promotion of mentoring and coaching policies, psychological consulting of both employers and employees, creation and development of managerial teams, prophylaxy and/ or reduction of professional exhaustion, establishment of objectives with motivational and ethic nature, etc. All these efforts will be felt in each domain, from banking, agriculture or IT\&C up to pharmacy, outsourcing or FMCG. With the aim of raising the quality of people's economic behaviour, psychology will probably reach the conclusion that the great financial crisis (with which we came out postmodernity while entering metamodernity) occurred because the economic system had been built up on an erroneous vision about the human being. If, times ago - when the postulates of classical economy were preferred - the idea that "individuals are capable of performing exact economic calculations and of taking the most rational decisions about their money" was acknowledged, the premise now put forth was that "most of the individuals are irrational and self-destructive, they frequently take wrong decisions, always repeat the same mistakes, are naive and easy-to-handle, not knowing to calculate the risks and performing emotional economic operations". The homo economicus once established by Adam Smith will appear as only an elementary theoretical concept. This time, priority will be granted to the efforts made for integrating the most recent advances registered in psychology in "a more flexible and more realistic explanation of human economic behaviour". In other words, focus will be laid on the elaboration of an economico-behavioural paradigm capable of "considering all fluctuations of human rationality, which can be equally affected by emotions, by the herd effect, by the marketing techniques in use or simply by the 
Bulletin of Integrative Psychiatry $\bigcirc$ New Series $\bigcirc$ June 2021 ○ Year XXVII ONo. 2 (89)/99

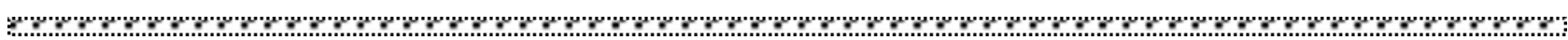
incompetency of making economic modern one, and if considering that calculations". metamodernity is an extension of modernity and postmodernity, metamodern psychology

The conclusion of all these considerations is that, in metamodernity, psychology acquires a new contour. This time, it aims at playing a full spiritual part in an epoch which values pragmatism and involvement, the capacity of deciphering people' conduct on the basis of strictly realistic data and on the idea of selfreconstruction through inter-relational communication, on the ability of grasping things in all their complexity and on the objective of installing a new existentialistic order, in which each situation expresses a unitary logic.

In spite of its significant distancing from the experience accumulated in the postmodern epoch and, even more, from that of the is not wholly detached from its previous manifestations, so that some assertions valid once will still be observed, such as: the existence of universal truths, the diversity and competition of paradigms, the presence of monolithic existentialistic factors, the importance of socio-cultural norms, of economic determinations and of arbitrarylinguistic conventions, etc. Therefore, metamodern psychology appears as a complex epistemological structure in whose composition originality matches ideally tradition, discontinuity - continuity, and classicism - full anchoring in contemporaneousness.

\section{ACKNOWLEDGEMENTS AND DISCLOSURES}

The author states that there is no declared conflicts of interest regarding this paper.

\section{REFERENCES}

22. Mention could have been here made of fragments included in: MUCCHIELLI, A. La nouvelle psychologie. Paris: P.U.F, 1993 ( Romanian version: MUCCHIELLI, A. Noua psihologie (translated by D. Grama). Bucureşti: Editura Ştiinţifică, 1996); GROF, S. Psychology of the Future. Albany, NY: State University of New York Press, 2000 and/ or ILIN, C.. Viitorul psihologiei muncii şi organizaţionale în perspectiva schimbărilor socio-economice-tehnologice din lumea muncii. In: Z. BOGATHY (coord.). Manual de psihologia muncii şi organizaţională. Iaşi: Polirom, 2004, pp. 317-326.

23. For further details, see ГУСЕЛЬЦЕВА, М. С. Смешанные методы в свете идеала постнеклассической рациональности. In: Психологические исследования, 2014, Том 7, № 36, с. 5(URL: http://psystudy.ru/index.php/ num/2014v7n36/1016-guseltseva36.html); ГУСЕЛЬЦЕВА, М. С. Принцип развития в современной психологии: вызовы полипарадигмальности и трансдисциплинарности. In: А. Л. ЖУРАВЛЕВА, Е. А. СЕРГИЕНКО (ред.). Разработка и реализация принципа развития в современной психологии. Москва: ИПРАН, 2016, с. 31-51; ГУСЕЛЬЦЕВА, М. С. Метамодернизм в психологии: новые методологические стратегии и изменения субъективности. In: Вестник Санкт-Петербургского университета. Психология, 2018, Том 8, Вып. 4, с. 327-340 (URL: https://doi.org/10.21638/11701/spbu16.2018.402) and/ or АСМОЛОВ, А. Г. От культуры полезности к культуре достоинства. In: Человек без границ, 2013(URL:http://asmolovpsy.ru/ sites/default/files/ot_kultury_poleznosti_k_kulture_dostoinstva.pdf ).

24. Interesting data on this topic may be found in ГУСЕЛЬЦЕВА, М. С. Метамодернизм в психологии: новые методологические стратегии и изменения субъективности. In: Вестник Санкт-Петербургского университета. Психология, 2018, том 8, вып. 4, с. 327-340(URL: https://doi.org/10.21638/11701/spbu16.2018.402) and/ or БАЗАРГАНИ, Д. Т., ЛАРСАРИ, В. Н. «Постмодернизм»: может ли современная ситуация быть описана термином «постмодерн»? Реферативный обзор постмодернизма и его критики в современных дидактических программах. In: Журнал Гефтер, 2015(URL: http://gefter.ru/archive/14194). 
(1) 25. For further details, see EPSHTEIN, M. N. De'but de siecle, ili Ot post- k proto-. Manifest novogo veka(De'but de siecle, or From post-to proto-. Manifesto of the New Century). In: Znamya, 2001, № 5, p. 11-17. Available at: http://magazines. russ.ru/znamia/2001/5/epsh.html (In Russian).

26. For further details, see ГРЕБЕНЮК, А. А. Теоретико-методологические основы метамодернистской психологии. Режим доступа: https://metaxy-psy.blogspot.com/p/blog-page 15.html; ГРЕБЕНЮК, А. А. Метамодернизм в психологии или возвращение из игры в реальную жизнь(Электронный ресурс). Режим доступа: http://metamod-errnzm.rn/метамодернизм-в-психологии; ГРЕБЕНЮК, А. А. Метамодернистская психотерапия: теоретические основания и решаемые задачи. In: Г. Ю. ГУЛЯЕВА (общ. ред.). Фундаментальные и прикладные научные исследования: актуальные вопросы, достижения и инновации: сборник статей III Международной научно-практической конференции. Пенза : Наука и Просвещение, 2017, c. 207-212 and/ or ГРЕБЕНЮК, А. А. Основы метамодернистской психологии(Электронный ресурс). Режим доступа: http://metamodernizm.ru/metamodernism-psy-chology.

27. The formulation is taken over from ARDILA, R. The future of psychology and the future of man. In: XXIII International Congres of Psychology: Volume des resumes. Acapulco, Mexico,1984, p. 178.

28. See also DENMARK, F. L., RUSSO, N.F. Virginia Staudt Sexton. In: A. N. O'CONNELL, N.F. RUSSO (Eds.). Women in Psychology: A Bio-bibliographic Sourcebook. New York, NY: Greenwood Press, 1990, pp. $285-289$.

29. As generally known, natural cataclysms (hurricanes, typhoons, earthquakes, drought, floods, etc.) are caused not only by the nature of earth's surface, by the processes occurring in the atmosphere or by the mutations the biosphere is subjected to, but also by an exponential population increase, by its high concentration in certain regions of the globe, by the massive industrialization of the seacoast zones, by megaconstructions which drastically restricts the easily flooded areas of rivers and/ or by ecological involutions. In the last 20 years, approximately three million persons were victims of natural cataclysms, while more than 800 millions suffered severe consequences. In the year 2011, the material damages produced by natural cataclysms amounted to 380 billion dollars, comparatively with the annual average value recorded until then, of 75 billion dollars. The continuous industrial increase, along with urbanization, concentration of populations in zones with high natural risk (first, in seacoast areas, occupied by $44 \%$ of world's population, where $4 / 5$ of the largest existing cities are placed) represent the main factors multiplying such type of risk. In recent years, the manifestation of dangerous natural phenomena has constantly increased. The risks of exceptional situations induced by the global modification of both climate and economic activities are huge for the population and, equally, for the economic objectives. In this respect, see also Catastrofele naturale. Avaliable at: ro.wikipedia.org/wiki/catastrofa_naturala and/ or Dezastre naturale. Available at: www.storyboardthat.com/ro/lessonplans/dezastre-naturale.

30. The technical-scientific progress - initiated in the middle of the XXth century, with the introduction, in productive activities, of large amounts of natural resources and with the utilization of complex technological systems - caused a substantial increase of technogenous type catastrophies. According to specialized opinions, such increase is first related to the application, in industrial and energetic domains, of a too high amount of chemical radiations and of technological processes with explosion risk. It has thus became obvious that the danger for people is generated by the environment he himself created. Data provided by the United Nations Organization shows that the incidents with technogenous character occupy the third position among all types of exceptional situations, concerning the number of human lives loss. The first place is held by hydrometeorological natural disasters (floods, tsunamis), and the second - by cataclysms of geological nature (earthquakes, landslides, volcanic erruptions, etc.). According to the data provided by the International Center Disadter Research, the mortality rate recorded by technogenous injuries produced between 19942007 was of 0.8 persons deceased at 1 million. Over the 2003-2006 period, the number of technogenous catastrophies increased several times, comparatively with the number of natural disasters. In the following years, the situation becomes even more critical. Thus, according to the data provided by the Schweizerische RückversicherungsGesellschaft A.G. Swedish Insurance Company, between 2006-2013, 8,700 human victims were recorded, while the sum of material losses attained 4 billion dollars. In the last ten years, at world level, the technogenous disasters produced about 600,000 deceases, and about 2 billion persons were wounded. In the years to come, the specialists of such statistics estimate that no significant changes will occur, which means that the number of persons affected by technogenous phenomena will increase. For further details, see TĂBÂRȚĂ, V., CAPRĂ, G. Pericolul catastrofelor contemporane cu caracter tehnogen. Available at: http://repository.utm.md/handle/5014/1004; Catastrofele cu caracter tehnogen. Available at: http://www.washprofile.org and/ or Centre for Research on the Epidemiology of Disasters (CRED). Available at: http://www.emdat.be.

31. Additional data on the topic in ГУСЕЛЬЦЕВА, М. С. Принцип развития в современной психологии: вызовы полипарадигмаль-ности и трансдисциплинарности. In: А. Л. ЖУРАВЛЕВА, Е. А. СЕРГИЕНКО (ред.). 
Bulletin of Integrative Psychiatry O New Series O June 2021 ○ Year XXVII ONo. 2 (89)/101

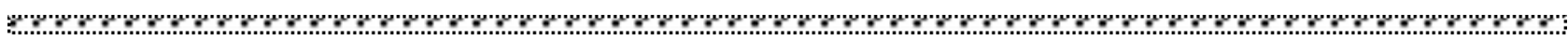
Разработка и реализация принципа развития в современной психологии. Москва: ИПРАН, 2016; ГРИШИНА, Н. В., КОСТРОМИНА, С. Н. Психология личности: переосмысление традиционных подходов в контексте вызовов современности. In: Психологические исследования, 2017, Т. 10, № 52, c. 1[URL: http://psystudy.ru/index.php/num/2017v10n52/1405-grishina52.html); ГУСЕЛЬЦЕВА, М. С. Смешанные методы в свете идеала постнеклассической рациональности. In: Психологические исследования, 2014, Т. 7, № 36, с. 5(URL: http://psystudy.ru/index.php/ num/2014v7n36/1016-guseltseva36.html) and/ or СЕРГИЕНКО, Е. А. Межпарадигмальные мосты. In: Психологические исследования, 2016, Т. 9, № 48, c. 4(URL: http://psystudy.ru/index.php/num/2016v9n48/1306-sergienko48.html).

32. ZLATE, M. Introducere în psihologie. Bucureşti: Casa de Editură şi Presă „ŞANSA” S.R.L., 1994, p. 50 and/ or ZLATE, M. Introducere în psihologie. Iaşi: Polirom, 2000, p. 71.

\section{Correspondence \\ Mihai Șleahtițchi, \\ Doctor habilitat (docteur d'État) in Psychology, PhD in Paedagogy, Professor, Republic of Moldova, mihai sleahtitchi@yahoo.com}

Submission: 10 sep 2020

Acceptance: 12 feb 2021 